\title{
The dissolved organic matter as a potential soil quality indicator in arable soils of Hungary
}

\section{Tibor Filep, Eszter Draskovits, József Szabó, Sándor Koós, Péter László \& Zoltán Szalai}

\section{Environmental Monitoring and Assessment}

An International Journal Devoted to Progress in the Use of Monitoring Data in Assessing Environmental Risks to Man and the Environment

ISSN 0167-6369

Volume 187

Number 7

Environ Monit Assess (2015) 187:1-12 DOI 10.1007/s10661-015-4700-6

\section{ENVIRONMENTAL MONITORING AND ASSESSMENT}

An International Journal devoted to progress in the use of monitoring
data in assessing environmental risks to Man and the environment. $\quad \begin{array}{r}\text { ISSN 0167-6369 } \\ \text { CODEN EMASDH }\end{array}$

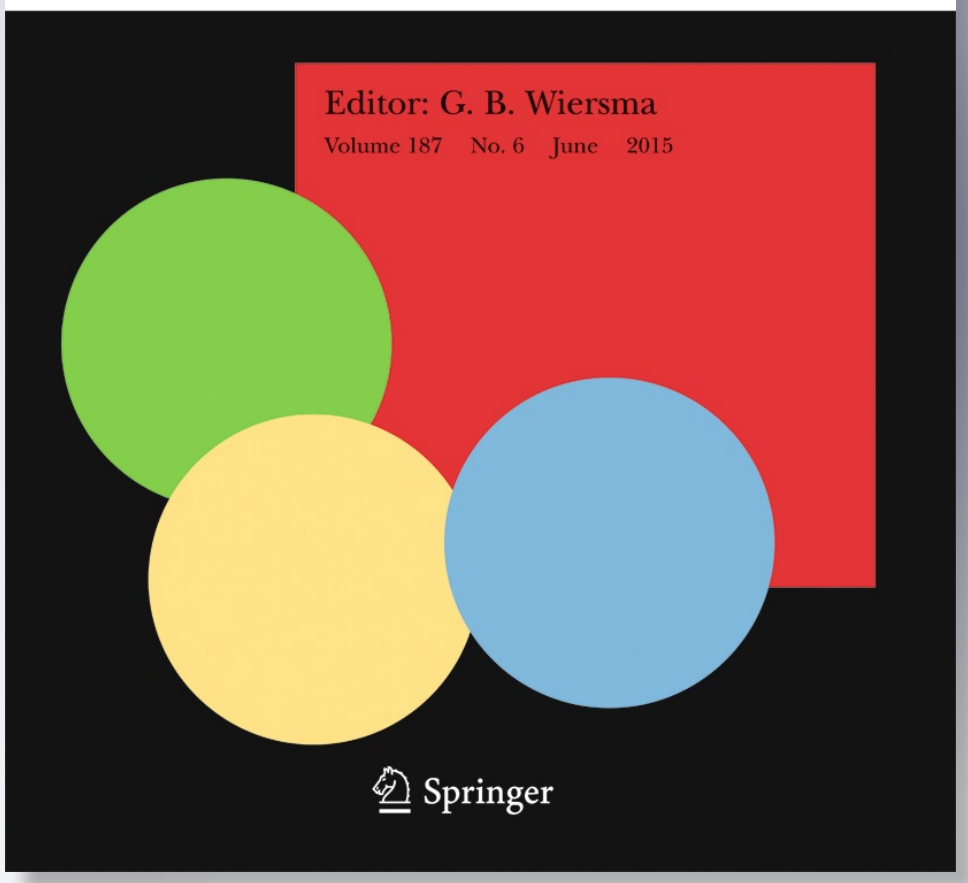

\section{望 Springer}


Your article is protected by copyright and all rights are held exclusively by Springer International Publishing Switzerland. This eoffprint is for personal use only and shall not be self-archived in electronic repositories. If you wish to self-archive your article, please use the accepted manuscript version for posting on your own website. You may further deposit the accepted manuscript version in any repository, provided it is only made publicly available 12 months after official publication or later and provided acknowledgement is given to the original source of publication and a link is inserted to the published article on Springer's website. The link must be accompanied by the following text: "The final publication is available at link.springer.com". 


\section{The dissolved organic matter as a potential soil quality indicator in arable soils of Hungary}

\author{
Tibor Filep • Eszter Draskovits • József Szabó • \\ Sándor Koós • Péter László • Zoltán Szalai
}

Received: 13 April 2015 / Accepted: 16 June 2015

(C) Springer International Publishing Switzerland 2015
Keywords Arable soil · Dissolved organic matter. DOC $\cdot$ Soil quality $\cdot$ SQI $\cdot$ SUVA

\section{Introduction}

When investigating the agricultural sustainability and/or the environmental aspects of soils, there are needs to create precise and sensitive indicators for evaluating soil quality. However, these indicators are usually not well defined, so specifying soil quality is a continuously improving paradigm of soil sciences (Qi et al., 2009). Furthermore, the definition of soil quality raises so many difficulties that it would be better to talk about the "concept of soil quality" as stated by Bastida et al. (2008). However, despite the difficulties met in defining them, the use of soil quality indicators is critical for ensuring the sustainability of agricultural ecosystems (Arshad and Martin, 2002).

Soil quality is determined to a great extent by organic matter content and quality, which can be affected by changes in soil conditions (Haynes, 2005; Undurraga et al., 2009; Wang et al., 2011). Consequently, SOM is considered to be an important indicator of soil quality (Doran and Parkin, 1994). However, the generally large amount of soil organic matter and the soil variability make it difficult to measure the effect of changes in soil use management or agricultural practices in the short term (Gregorich et al., 1994; Fließbach et al., 2007). This means that it is difficult to measure changes in the SOM of the soils in a relatively short period (e.g. 15 years). Labile organic matter fractions (e.g. the light 
fraction of $\mathrm{C}$, microbial biomass $\mathrm{C}$, dissolved organic carbon), however, can respond rapidly to environmental changes (Haynes, 2000). The estimated DOM fluxes are 1-2 orders of magnitude smaller than the whole transfer of organic matter in ecosystems (Michalzik et al., 2001), so small changes in the organic carbon balance could result in large changes in DOM (Aitkenhead and McDowell, 2000). Because of this, it has been proposed that this labile fraction of the soil (quantified as DOC) could be used as an indicator of soil fertility, and consequently of soil quality (Haynes, 2000; Neff and Asner, 2001).

Although simple soil quality indicators are easy to apply, the use of two or more parameters in a soil quality index makes it possible to give a better characterization of soil quality. Therefore, to obtain an index that provides and integrates more information on the quality of a given soil, multiparametric indices have been developed for agro-ecosystems and for non-agricultural soils (Bastida et al., 2008). In this case, the soil quality indicators should be a combination of chemical, physical and biological properties (Herrick et al., 2002; Aparicio and Costa, 2007) and the indicator values can be combined into a quantifiable soil quality index (SQI). A valid SQI would thus help integrate and interpret data from various soil measurements, and indicate whether the land use was having a desired effect on productivity, environmental protection and health (Granatstein and Bezdicek, 1992).

Although DOM is considered to be a potential quality indicator for arable soils (Haynes and Tregurtha, 1999; Haynes, 2000; Silveira, 2005) and an effort by Jones et al. (2014) to investigate whether different soil classes and vegetation cover types having different DOC concentrations, the evaluation and validation of DOM with a complex quality indicator has not yet been reported. In this paper, the dissolved organic matter in soils was evaluated as a potential soil quality indicator, and its limitations were shown on 190 Hungarian agricultural soils. Relationships between DOM parameters $\left(\mathrm{DOC}\right.$ and $\mathrm{SUVA}_{254}$ ) and a multiparametric soil quality index (SQI) were identified based on minimum data sets of the chemical, physical and biological parameters of soils. Two different approximations were applied to decide whether DOC and SUVA $_{254}$ are satisfactory soil parameters for use as soil quality indicators. First, a qualitative evaluation was done, including a comparison of the effect of different soil types on SQI values and DOC concentrations. Secondly, regression analysis was applied to give a quantitative approximation of the relationship between SQI values and DOM parameters.

\section{Materials and methods}

\section{Soil characteristics}

In this study, 190 samples were analysed from soil database for agricultural areas in Hungary. Hungary lies in the temperate zone and is situated at the convergence of three main climatic regions: the Oceanic, the Continental and the Mediterranean. The mean annual temperature of the country is $10{ }^{\circ} \mathrm{C}$, while the annual average rainfall is about $600 \mathrm{~mm}$ (Ódor et al., 1998).

The arable soil samples were obtained from the Soil Monitoring System of Hungary (SMS; Várallyay, 1994). The soil samples were representative of the agricultural soils of Hungary, comprising 45 gleysols, 32 chernozems, 27 luvisols, 21 cambisols, 16 fluvisols, 11 greyzems, 10 arenosols, 8 phaeozems, 7 leptosols, 5 regosols, 4 solonetzes, 2 podzoluvisols and 2 vertisols. All samples were taken from the top $20 \mathrm{~cm}$ of the soils between 15th September and 15th October in 2004. All the samples were air-dried and sieved through a 2-mm stainless steel mesh.

The following soil parameters were determined: $\mathrm{pH}$ (measured in $\mathrm{H}_{2} \mathrm{O}$ and $\mathrm{KCl}$ ), soil organic matter (SOM), hydrolytic acidity ( $\mathrm{HAC}), \mathrm{CaCO}_{3}$, particle-size fractions (sand, silt, clay), cation exchange capacity (CEC), electrical conductivity (EC), soil respiration (SR), cellulose digestion activity (CDA), dehydrogenase activity (DHA), dissolved organic carbon (DOC), total soluble N (TSN) and specific UV absorbance (SUVA) (Table 1).

\section{Laboratory analysis}

The soil $\mathrm{pH}$ was measured in 1:2.5 soil:water and soil:1M KCl suspensions $12 \mathrm{~h}$ after mixing (MSZ-080206/2:1978). The organic matter content was determined using the modified Walkley-Black method (Walkley and Black, 1934), digesting the soil organic matter with $5 \% \mathrm{~K}_{2} \mathrm{Cr}_{2} \mathrm{O}_{7}$ and cc. $\mathrm{H}_{2} \mathrm{SO}_{4}$ and analysing the colour of the suspension, which was related to the organic matter content of the samples, colorimetrically (MSZ-08-0452:1980). For the measurement of hydrolytic acidity (HAC), the soil samples were treated with $0.5 \mathrm{M}$ Ca-acetate adjusted to $\mathrm{pH} 8.2$, using a 1:2.5 soil/extractant ratio. The suspensions were then shaken for an hour and filtered. The filtrate was titrated with $0.1 \mathrm{M} \mathrm{NaOH}$ solution, and the hydrolytic acidity was calculated from the amount of base used (MSZ-08-0206/ 2:1978). The $\mathrm{CaCO}_{3}$ content was measured with a calcimeter; the soil was mixed with diluted $\mathrm{HCl}$ solution 
Table 1 Statistical properties of the soil parameters determined in the samples of Soil Monitoring System (SMS) of Hungary

\begin{tabular}{|c|c|c|c|c|}
\hline & $n$ & Min & Max & Mean $^{\mathrm{a}}$ \\
\hline $\mathrm{pH}\left(\mathrm{H}_{2} \mathrm{O}\right)$ & 190 & 4.6 & 8.2 & $7.1 \pm 0.85$ \\
\hline $\mathrm{pH}(\mathrm{KCl})$ & 186 & 3.6 & 8.1 & $6.3 \pm 1.0$ \\
\hline $\mathrm{HAC}\left(\mathrm{cmol} \mathrm{kg}^{-1}\right)$ & 188 & 0.00 & 35.2 & $4.5 \pm 6.9$ \\
\hline $\mathrm{CaCO}_{3}(\%)$ & 184 & 0.00 & 20.0 & $2.5 \pm 3.9$ \\
\hline SOM (\%) & 190 & 0.52 & 5.3 & $2.2 \pm 1.0$ \\
\hline $\mathrm{CEC}\left(\mathrm{cmol} \mathrm{kg}^{-1}\right)$ & 186 & 3.4 & 61.7 & $22.5 \pm 12.2$ \\
\hline $\mathrm{EC}\left(\mathrm{dS} \mathrm{m} \mathrm{m}^{-1}\right)$ & 137 & 3.8 & 25.0 & $8.7 \pm 3.6$ \\
\hline Sand $(\%)$ & 188 & 10.4 & 94.1 & $48.3 \pm 21.3$ \\
\hline Silt (\%) & 187 & 1.3 & 50.3 & $25.3 \pm 11.0$ \\
\hline Clay (\%) & 188 & 2.8 & 61.6 & $25.9 \pm 12.7$ \\
\hline $\mathrm{TSN}\left(\mathrm{mg} \mathrm{kg}^{-1}\right)$ & 188 & 2.39 & 166.1 & $32.4 \pm 24.3$ \\
\hline DHA $\left(\mathrm{g} \mathrm{kg}^{-1}\right.$ day $\left.^{-1}\right)$ & 174 & 0.00 & 0.49 & $0.11 \pm 0.08$ \\
\hline $\mathrm{SR}\left(\mathrm{mg} \mathrm{CO} \mathrm{Cg}^{-1} \mathrm{~h}^{-1}\right)$ & 176 & 0.00 & 4.6 & $1.1 \pm 0.79$ \\
\hline CDA $(\%)$ & 190 & 0.30 & 88.3 & $24.2 \pm 21.2$ \\
\hline $\mathrm{DOC}\left(\mathrm{mg} \mathrm{kg}^{-1}\right)$ & 189 & 25.1 & 364.9 & $100.9 \pm 45.0$ \\
\hline SUVA $\left(1 \mathrm{mg}-\mathrm{C}^{-1} \mathrm{~m}^{-1}\right)$ & 189 & 0.6 & 7.5 & $3.3 \pm 1.1$ \\
\hline
\end{tabular}

${ }^{\mathrm{a}}$ Mean \pm standard deviation

and the volume of $\mathrm{CO}_{2}$ released was determined (Loeppert and Suarez, 1996; MSZ-08-0206/2:1978). Particle-size distribution was determined by the pipette method. The soil:water suspension was mixed in a sedimentation cylinder, then sampled with a pipette to collect particles of a given size (MSZ-08-0215:1978).

The CEC of the soils was measured by the modified method of Mehlich (1948) (MSZ-08-0215:1978). Electrical conductivity was measured in soil saturated with water up to the upper limit of plasticity (MSZ-08-0206/ 2:1978). Soil respiration was determined as the $\mathrm{CO}_{2}$ produced during $100 \mathrm{~h}$ of aerobic incubation at $18{ }^{\circ} \mathrm{C}$. The $\mathrm{CO}_{2}$ concentration was determined as methane by gas chromatography with an FID detector (ISO 16072, 2002). Cellulose degradation was measured in the laboratory as the decrease in weight of a Whatman No. 1 filter paper in the soil (MSZ-08-1931:1984). The determination of dehydrogenase activity was based on the reduction of 2,3,5-phenyl tetrazolium chloride as substrate. The triphenyl formazan formed in the enzymecatalysed process was measured by spectrophotometry and expressed as formazan $/ 1 \mathrm{~g}$ soil with original moisture/1 day (MSZ-08-1721-3:1986).

DOC was measured after extraction with $0.01 \mathrm{M} \mathrm{CaCl}_{2}$ at a 1:10 soil:solution ratio for $2 \mathrm{~h}$ (Jászberényi et al., 1994) in a TOC/TN analyser (Tekmar Dohrmann Apollo 9000) using combustion $\left(680^{\circ} \mathrm{C}\right)$ with a platinum catalyst. Total soluble $\mathrm{N}$ (TSN) content was measured from the $\mathrm{CaCl}_{2}$ extraction using Continuous Flow Analyzer (CFA). Specific UV absorption ( $\mathrm{SUVA}_{254}$ ) was calculated by dividing the absorption at $254 \mathrm{~nm}$ by the DOC value.

Data analysis

Outlier identification is important in many applications of multivariate analysis, so univariate outliers were removed by estimating the z-scores of the data using Eq. 1 and eliminating those with values between -3 and 3 :

$z_{i}=\frac{x_{i}-\mu}{\sigma}$

where $\mu$ and $\sigma$ are the mean and standard deviation of the variable, and $z_{\mathrm{i}}$ and $x_{\mathrm{i}}$ the standard score and the value of the variable in sample $i$.

Differences in the SQI and DOC values of the soil types were tested by one-way ANOVA with Duncan's post hoc test $(p<0.05)$. Regression analysis was performed to quantify how the SQI of different sites influenced DOC and $\mathrm{SUVA}_{254}$.

Soil quality index

\section{Soil indicator scoring}

Standard scoring functions (SSF) were determined (Andrews et al., 2002) to score the soil indicators (Table 2). Three types of SSFs are typically used for soil quality assessment: (i) 'More is better'; (ii) 'Less is better' and (iii) 'Optimum' (Liebig et al., 2001). The equation defines a 'More is better' scoring curve for positive slopes, a 'Less is better' curve for negative slopes and an 'Optimum' curve when a curve is reflected at the

Table 2 Score functions of soil parameters selected by PCA

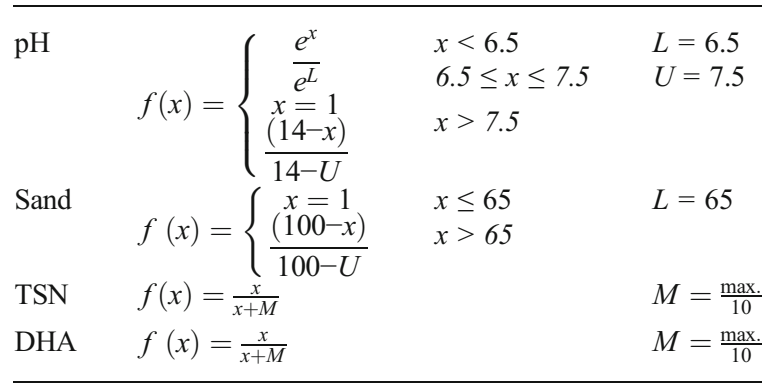

$L$ lower limit

$U$ upper limit 
upper threshold value. 'More is better' curves score soil properties that are associated with improved soil quality at higher levels, e.g. CEC, SOM and DHA, so the highest observed value received a score of 1 while all others received a score of $<1$. 'Less is better' indicators (e.g. EC) are those that indicate poor quality at high levels. 'Optimum' curves score properties that have an increasingly positive influence on soil quality up to an optimal level beyond which their influence is detrimental. Soil quality indicators, such as $\mathrm{pH}$, were rated using this curve.

The values of TSN, DHA were scored following the Michaelis-Menten kinetics, which is a combination of zero and first-order kinetics (Wagner, 1973) and reflects the nature of the biogeochemistry of these parameters.

\section{Indicator selection}

The identification of representative soil quality indicators is a key concern of soil quality evaluation. The data collected from the various soil analyses were reduced to a minimal data set (MDS) using principal component analysis (PCA) (Andrews and Carroll, 2001; Andrews et al. 2002) with the SPSS 16.0 program. The results of PCA (data not shown) on a given data set generate a number of principal components (PC), which are linear combinations of the variables that account for maximum variance. The PCs having high eigenvalues and comprising variables with high factor loading were assumed to be the variables that best represent the system attributes. Therefore, only PCs with eigenvalues $>1.0$ were selected (Brejda et al., 2000). Within each PC, variables with high factor loading (i.e. those with absolute values for factor loading within $10 \%$ of the highest value) were retained for the MDS. To reduce redundancy of data, Pearson's correlation coefficients were used (Andrews and Carroll, 2001); if the highly weighted variables were not correlated (taken as a correlation coefficient of $<0.60$ ), then each was considered important and was retained in the MDS. Among the well-correlated variables within each PC $(r>0.60)$, the variable with the highest sum of correlation coefficients was chosen for the MDS (Andrews and Carroll, 2001; Karlen et al., 1997). The SQI was calculated for each treatment from the following:

$\mathrm{SQI}_{i}=\sum_{i=1}^{n} W_{i} \times S_{i}$

where $W$ is the PC weighting factor, $S$ is the indicator score for each variable $i$, and $n$ is the number of variables in the MDS. In order to apply this equation, the values of $S$ and $W$ needed to be determined.

After calculating the $\mathrm{S}$ values for all the MDS variables, each property was weighted using the PCA results. Each PC explained a certain amount (\%) of the variation in the total data set. This percentage, when divided by the total percentage of variation explained by all the PCs with eigenvalues $<1.0$, provided the weighting factor $(W)$. Having determined the values of $S$ and $W$, the SQI for each sample was then calculated using the equation above. Higher index scores mean better soil quality.

\section{Results}

SQI calculation

The indicators selected by PCA were transformed using scoring functions, and the SQI was calculated using weighting factors for each scored MDS variable. For the SMS database, the following formula was obtained:

$$
\begin{aligned}
\mathrm{SQI}_{\mathrm{SMS}}= & \sum_{i=1}^{n} 0.36 \times S_{\mathrm{sand} i}+0.26 \times S_{\mathrm{pH} i} \\
& +0.22 \times S_{\mathrm{TSN} i}+0.16 \times S_{\mathrm{DHA} i}
\end{aligned}
$$

where $S$ is the score for the subscripted variable and the coefficients are the weighting factors derived from PCA.

SQI values obtained for agricultural soils

The SQIs obtained for agricultural soils have negatively skewed distribution, with a mean of 0.71 and a range of 0.34 to 0.90 for SMS database (Fig. 1). Qi et al. (2009) found that 431 samples of Cambisols and Anthrosols showed a symmetric, normal distribution, and $90 \%$ of the samples were in the moderate quality category (between 0.68 and 0.78 ) according to their classification.

Variations between the SQI and DOC values of soil types

Figures 2 and 3 represent the values of SQI and DOC for the different soil classes. The DOC concentration varied from 58 to $156 \mathrm{mg} \mathrm{kg}^{-1}$.

One-way ANOVA showed a clear difference in soil quality between the soil types (Fig. 2): low soil quality in arenosols with an average SQI of 0.5 and significantly 
Fig. 1 Distribution of soil quality indices for agricultural soils of Hungary

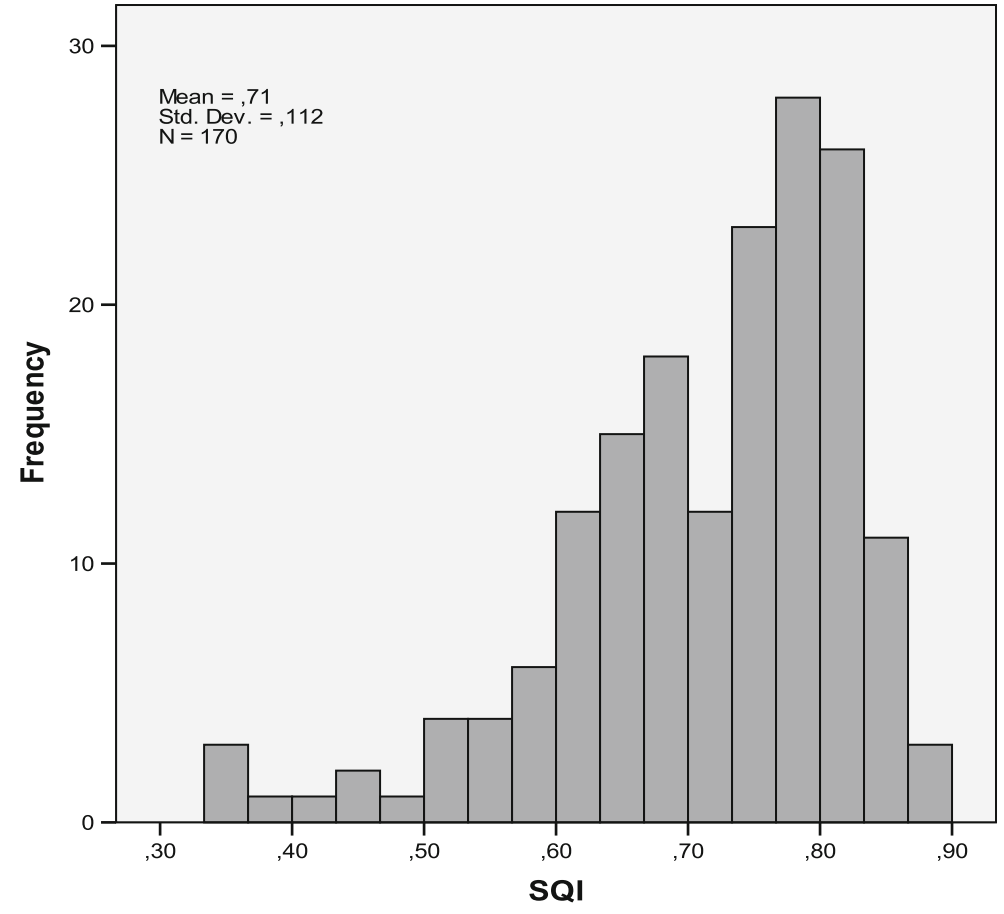

higher soil quality for groups such as gleysols, vertisols, regosols, solonetzes and chernozems. Moderate soil quality indexes were found for leptosols, luvisols, cambisols, luvisols and greyzems.

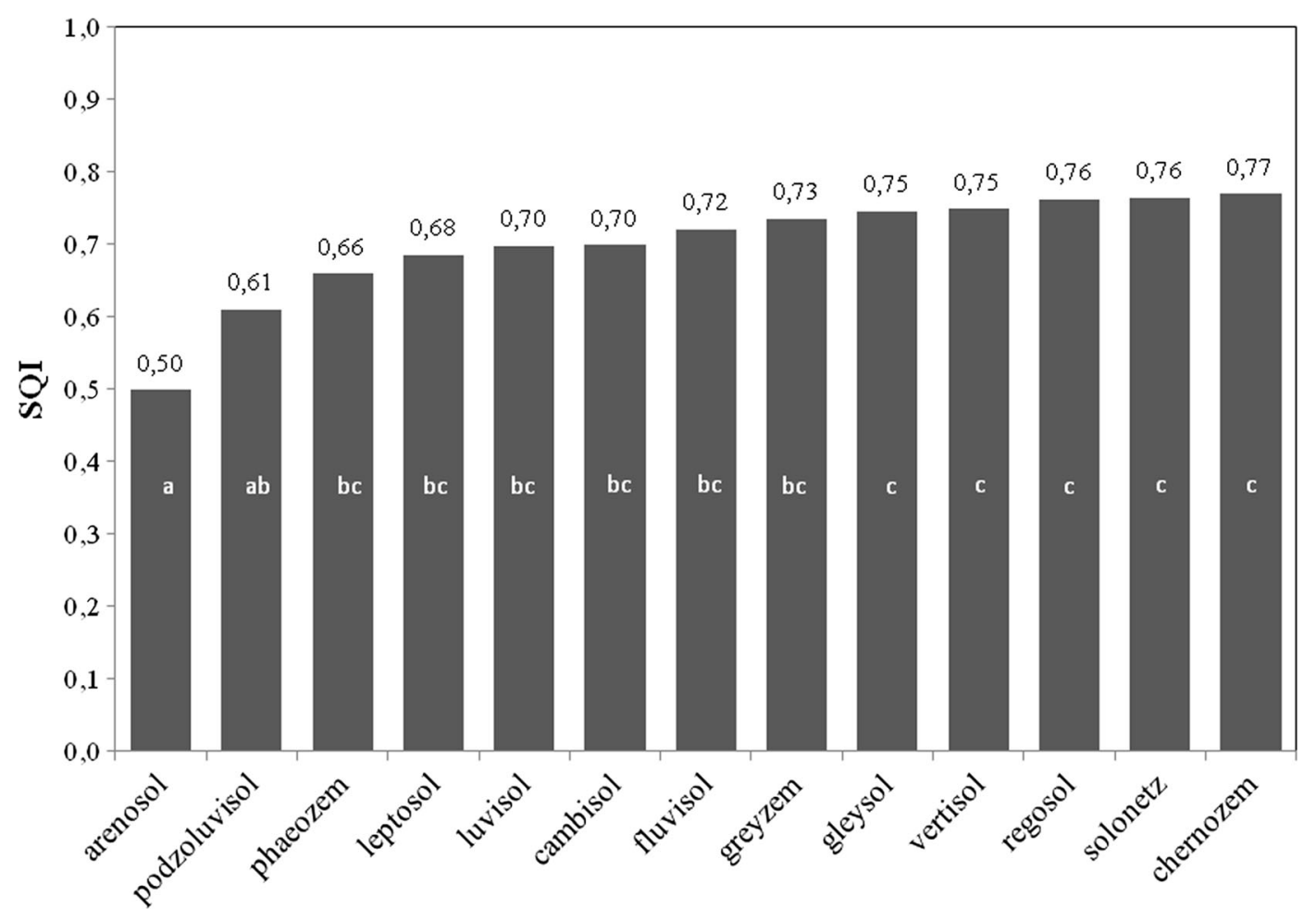

Fig. 2 Effect of soil type on the soil quality index $(a-c$ indicates significant differences within each bar at the $5 \%$ level of probability according to Duncan test) 


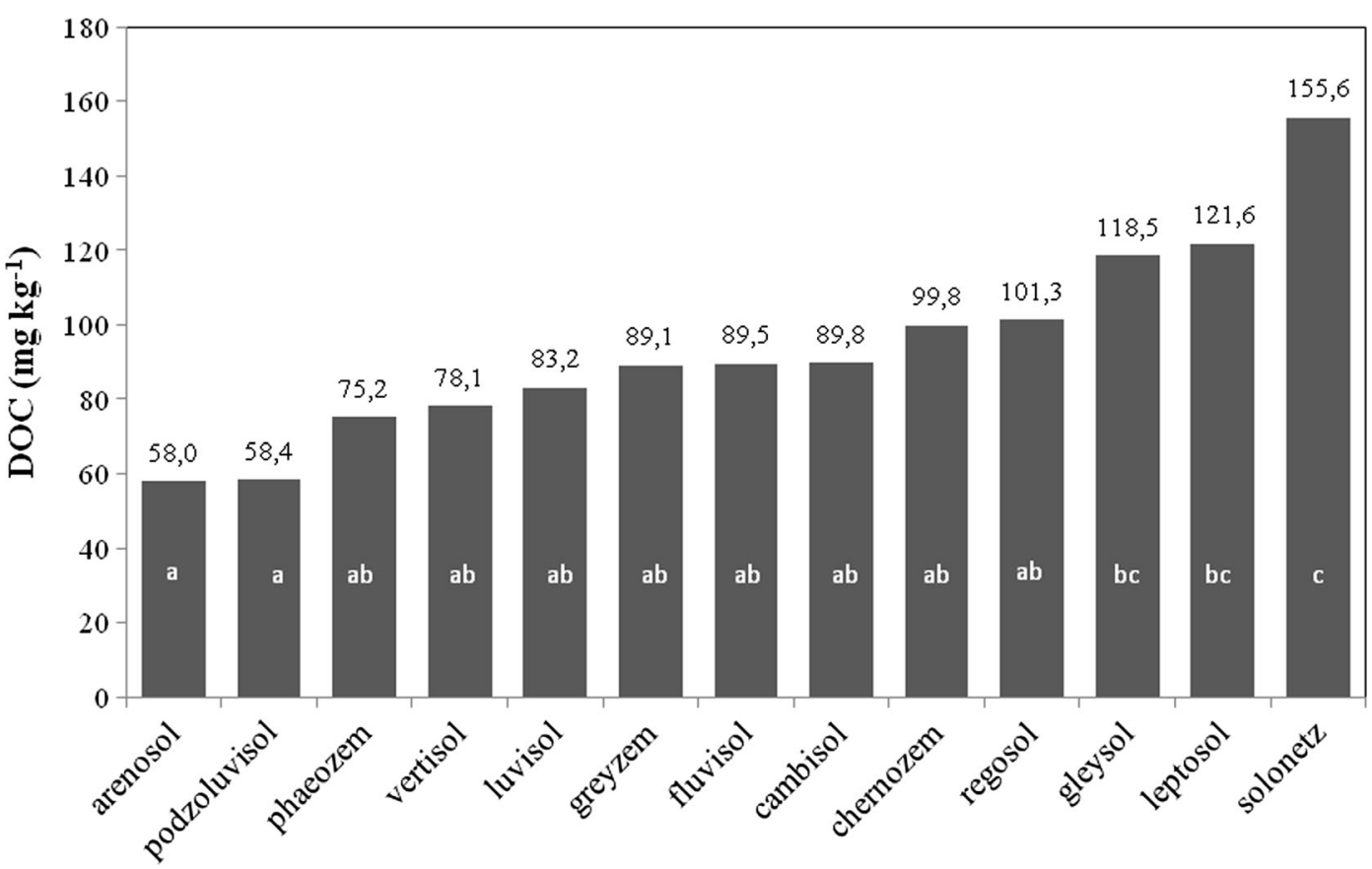

Fig. 3 DOC variations among soil classes ( $a-c$ indicates significant differences within each bar at the $5 \%$ level of probability according to Duncan test)

The grouping of the soil types in terms of mean DOC values was similar to that obtained on the basis of SQI (Fig. 3), with the lowest DOC content for arenosols, podzoluvisols, phaeozems and vertisols, while solonetzes had the highest DOC value.

A clear similarity was revealed between the effect of the soil classes on the soil quality index and the DOC concentration (Figs. 2 and 3). For most of the soil types, e.g. arenosols, phaeozems, luvisols, solonetzes etc., the ranking of the soil types was similar on the basis of SQI and DOC.

\section{Relationships between SQI and DOM parameters}

\section{Correlation between DOC and SUVA 254}

It is important to know how the dissolved organic matter parameters (DOC and $\left.\mathrm{SUVA}_{254}\right)$ are correlated with each other. There was a significant correlation between DOC and SUVA $_{254}$ (with a Pearson's coefficient of $-0.549, p<0.001$ ); however, regression between these parameters was not linear (Fig. 4). A nonlinear, exponential function was obtained for the DOCSUVA $_{254}$ relationship in the present study, as also reported in a study on extracts from composts (Zmora-Nahum et al., 2007).

\section{SQI vs. DOC and SUVA}

After showing the considerable agreement between the SQI and DOC scales, regression analysis was performed to reveal quantitative relationships, since the correlation analysis can only be used to investigate linear relationships.

Regression analysis showed a non-linear relationship between DOC and SQI and a linear correlation between SUVA and SQI (Fig. 5). Clear trends emerged for the SQI-DOC and SQI-SUVA regressions in the SMS dataset; however, the regression equations obtained for the dataset, displayed in Table 3, showed that there was only one significant relationship between the variables: a relatively weak, but significant correlation for DOC $\left(R^{2}=0.157\right)$, while the remainder were not significant, with $R^{2}$ values of 0.021 for $\mathrm{SUVA}_{254}$.

\section{Discussion}

Qualitative approximation: effect of soil type on SQI and DOC concentration

Figures 2 and 3 indicate that there is a match between DOC and SQI regarding the soil types. In general, the 
Fig. 4 Relationship between DOC and SUVA $_{254}$ based on Soil Monitoring System of Hungary (SMS)

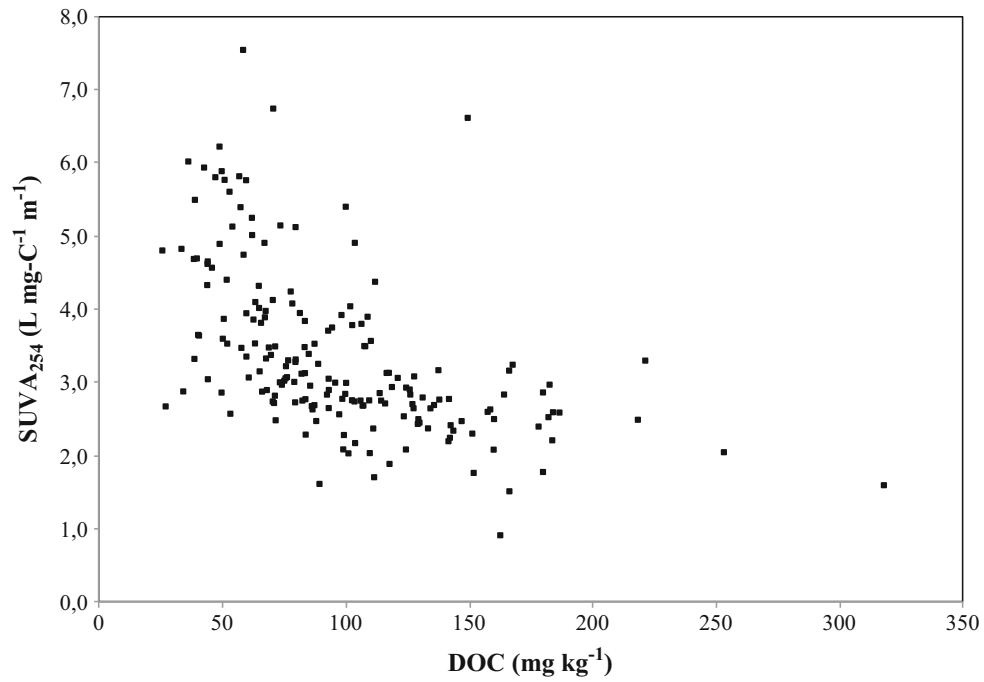

most dominant factor explaining the DOC concentration of soils is the SOM content (Filep and Rékási, 2011). Chernozem and gleysol soils had the highest SOM values in this study (2.98 and $2.76 \%$, respectively), while arenosols had the lowest one $(0.97 \%)$. This is in agreement with present knowledge on the limited formation of well-humified soil organic matter and stable organo-mineral complexes in coarse soils. In addition, it is known that a rapid turnover of organic matter exists in coarse-textured soils in arid and semiarid regions (Quiroga et al., 1999), so most plant and animal residues incorporated into the soil will be mineralized (Gregorich et al., 1994).

The pattern based on the SOM content of soil is modified by the mineralization rate of the soil and the aggregate size (Zech et al., 1997). In the case of vertisols, there is a mismatch; vertisols may have

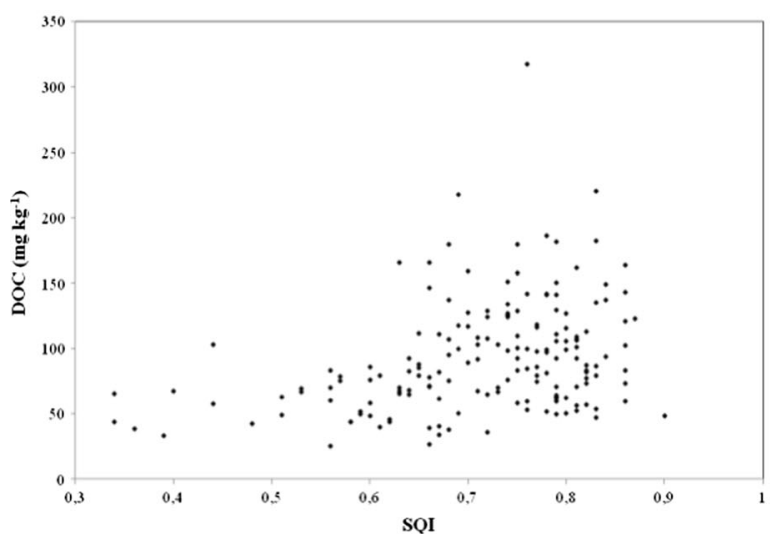

high denitrification potential, allowing easily decomposable organic material to be leached from the top soil. Moreover, many studies have shown that organic $\mathrm{C}$ mineralization increases and $\mathrm{C} /$ nutrient ratios decrease with decreasing aggregate size (Chichester, 1969; Anderson et al., 1981).

Although Myers and McGarity (1971) reported appreciable denitrification activity in solonetzic subsoils enriched by DOC leaching from the surface horizons, such enriching of the DOC content of the topsoil was not observed in this study, resulting in the highest DOC values $\left(156 \mathrm{mg} \mathrm{kg}^{-1}\right)$ for solonetz soils. The differences in respiration between chernozem and solonetz suggested that the higher carbon turnover rates in the chernozem soils could explain the differences observed between the rankings obtained with the SQI and DOC scales. Although podzolization typically caused a mobilization of

Fig. 5 Relationships for soil quality index (SQI) and DOM parameters

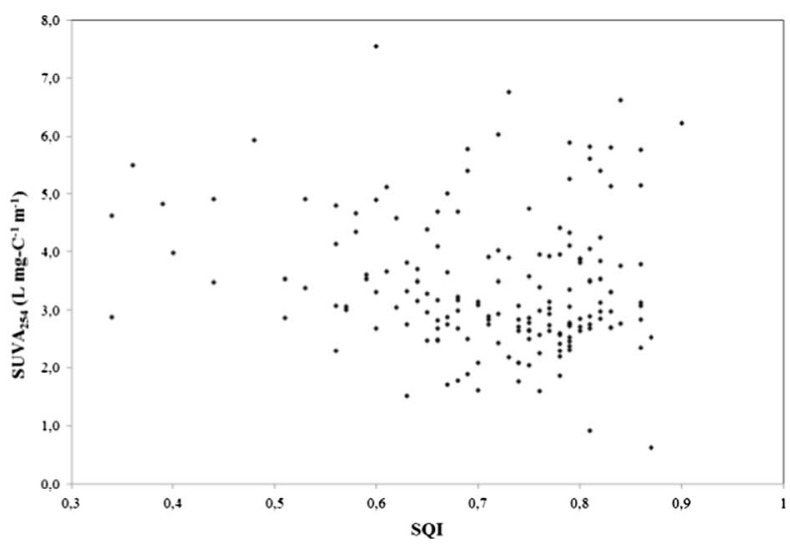


Table 3 Regression equation for DOC and $\mathrm{SUVA}_{254}$ with soil quality index (SQI) in the SMS dataset $(n=190)$

\begin{tabular}{lll}
\hline Equation & $\begin{array}{l}\text { Coefficient of } \\
\text { determination }\end{array}$ & Probability \\
\hline $\mathrm{SQI}=27.2 \mathrm{e}^{1.6 \mathrm{DOC}}$ & $R^{2}=0.157$ & $p<0.001$ \\
$\mathrm{SQI}=-1.5 \mathrm{SUVA}+4.5$ & $R^{2}=0.021$ & $p=0.057$ \\
\hline
\end{tabular}

DOC, mature spodosols might be a net DOC source (McClain et al., 1997), explaining why podzoluvisols had a DOC value of only $58.4 \mathrm{mg} \mathrm{kg}^{-1}$ in this study.

Quantitative evaluation: relationship of SQI with DOC and $\mathrm{SUVA}_{254}$

The fundamental aim of soil quality research is to discover single soil parameters which are largely determined by soil attributes, so that variation in these parameters would reflect changes in soil quality in response to treatments or natural processes. Since the DOC concentration was greatly influenced by soil parameters such as $\mathrm{pH}$, SOM content and texture, it has the potential to indicate changes in soil quality. In previous studies (e.g. Kalbitz et al., 2000; Filep and Rekasi, 2011), significant relationships were found between the DOC concentration of the soil and fundamental parameters.

As reported above, the $\mathrm{pH}$, sand content, total soluble $\mathrm{N}$ (TSN) and dehydrogenase activity (DHA) were selected by MDS for creating SQI values for the SMS dataset, which involves 190 soils from agricultural areas. It was interesting to note that the $\mathrm{Mg}$ content of soil was highly correlated with the soil texture. The correlation between these factors and dissolved organic matter will be discussed below.

Soil acidity, measured as the $\mathrm{pH}$ of the soil, has a substantial but contradictory influence on DOM dynamics through abiotic and biotic parameters (Kalbitz et al., 2000; Ji et al., 2014). Almost all laboratory studies revealed that DOC release was in positive correlation with soil pH (Curtin and Smillie, 1986; You et al., 1999). Various mechanisms have been suggested to explain this phenomenon, such as an increase in organic matter solubility (Erich and Trusty, 1997; Tombácz and Rice, 1999), increased microbial activity, an increase in the production of soluble molecules (Guggenberger et al., 1994) due to the decrease in biologically toxic
Al at higher pH (Castro Filho and Logan, 1991), and the displacement of the previously adsorbed DOM by other mobilized anions (Vance and David, 1992). However, other mechanisms, such as the microbial consumption of DOM (Kemmitt et al., 2006) and DOM flocculation or adsorption by cation bridging due to higher $\mathrm{Ca}^{2+}$ concentrations (Römkens and Dolfing, 1998), might also decrease the DOC concentration.

The positive relationship between organic matter and silt + clay (or the negative correlation with sand) can be attributed to the existence of organo-mineral complexes, the amount of which increases parallel with that of the fine fraction (Nichols, 1984; Sollins et al., 1996). It is likely that the changing organic matter content of the soils with alterations in soil texture had an effect on the DOC concentration.

The effect of the $\mathrm{N}$ status of the soils on DOC has not yet been clearly established (Chantigny, 2003). For arable soils, decreasing mineral $\mathrm{N}$ content was related with an increase in DOC concentration (Chantigny et al., 1999). However, Rochette and Gregorich (1998) found no effect of $\mathrm{N}$ addition on the DOC content of arable soils. Soil $\mathrm{N}$ may simultaneously stimulate DOC production and consumption processes, so the net effect is hard to predict under field or even laboratory conditions.

Dissolved organic compounds are the primary substrates for microorganisms (Jones et al., 2005). DHA, commonly used as an index to describe the microbial activity of soils, is related to soil respiration and thus to the decay and formation of DOC compounds (van Hees et al., 2005).

UV spectroscopy can provide valuable structural information about dissolved organic matter structure (Weishaar et al., 2003), because the absorbance of a molecule depends on the electron structure of the molecule. The UV spectrum, therefore, indicates the presence of specific bonding arrangements in the molecule. In the case of absorption in the near UV range (200$380 \mathrm{~nm}$ ), conjugated systems, such as those in aromatic molecules, generally have the greatest absorptivities (Silverstein et al., 1974). Therefore, the SUVA value, calculated by dividing the absorbance at $254 \mathrm{~nm}$ by the DOC concentration, is indicative of the aromaticity of dissolved organic matter. This means that high SUVA values indicate a relatively high proportion of aromatic carbon in the DOC fraction. Furthermore, an extract with a high DOC concentration and a low value of SUVA would be expected to be rich in aliphatic components (e.g. soluble sugars, fatty acids). 
Fig. 6 Envelope curve for SQIDOC function based on a trend line through the points identified by triangles

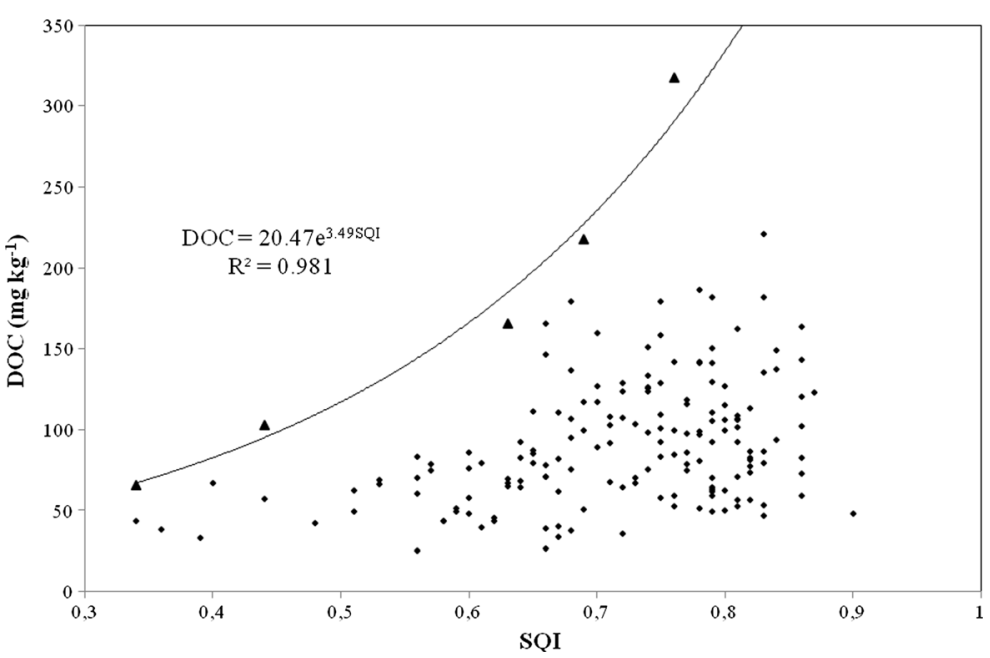

Although there was weak correlation between the SUVA values of DOC and SQI, the trend is clear; lower SQI values were associated with high SUVA values, while soils with high SQI had relatively low SUVA values. The metabolism of aromatic carbon is very different from that of aliphatic carbon. The aromatic rings of the organic compounds are generally very recalcitrant, so mineralization is limited. Previous studies showed that management practices can affect DOC properties, e.g. long-term manure input increased the aromaticity of DOC (Marschner and Kalbitz, 2003). This may cause a dysfunction in microbial activity and consequently in the nutrient status of the soil.

Estimation of the potential of DOC as a soil quality indicator

Although a weak correlation was obtained between SQI and DOC, the tendency of the relationship is unambiguous. In many soil samples, low DOC concentrations were measured at high SQI values; however, high concentrations of DOC were all associated with high values of SQI (from 0.60). A high value of DOC can thus be assumed to indicate a high SQI value, and consequently high soil quality. On the other hand, a low DOC concentration does not necessarily signify that the given soil has low quality.

In many cases, envelope curves have been used for evaluating the relationships between plant characteristics and meteorological properties. Because envelope curves provided supplementary tools to assess the potential of indicators for ecological systems (Stockle and Debaeke,
1997), such functions were used to reveal the potential of DOM for use as a soil quality indicator. Instead of the standard minimisation of the sums of squares, an upper envelope curve was fitted to the data (Fig. 6).

The envelope curve shows the robust potential of DOC to indicate changes in soil quality, as the regression equation had a high $R^{2}$ value. Points below the envelope curve may indicate the soil quality of a given sample, but there are some limitations due to the contradictory processes often taking place in the soil. As discussed above, the soil $\mathrm{pH}$ and the $\mathrm{N}$ status or texture of the soil not only have a direct effect on DOM but also indirectly control the DOC concentration. In general, the DOC concentration of a given soil is the result of numerous, often contradictory processes, leading to a wide scattering of the data.

\section{Conclusions}

The DOC concentration was greatly influenced by the physical and chemical processes taking place in different soil types. The similar trends observed for the soil quality index (SQI) and DOC in different soil types showed the possibility of using DOC as a soil quality indicator. The dynamic nature of dissolved organic matter makes it a plausible soil quality indicator. Despite the weak correlation detected between SQI and DOC, the tendency was unambiguous; although low DOC concentrations were measured in many soil samples at high SQI values, high DOC concentrations were always associated with high values of SQI (from 0.60). 
High values of DOC are thus a clear indication of high SQI values and consequently of high soil quality, while low DOC concentrations do not necessarily signify that the given soil has low quality. Thus, a clear tendency was illustrated using an envelope curve, which showed the robust potential of DOC to indicate changes in soil quality. This indicates that the dissolved organic matter fraction could be applied for evaluating soil quality, with some limitations which can be eliminated by the simultaneous use of other indicators.

\section{References}

Aitkenhead, J. A., \& McDowell, W. H. (2000). Soil C:N ratio as a predictor of annual riverine DOC flux at local and global scales. Global Biogeochemical Cycles, 14, 127-138.

Anderson, D. W., Saggar, S., Bettany, R. J., \& Stewarts, J. W. B. (1981). Particles size fractions and their use in studies of soil organic matter: I. The nature and distribution of forms of carbon, nitrogen and sulfur. Soil Science Society of America Journal, 45, 767-772.

Andrews, S. S., \& Carroll, C. R. (2001). Designing a soil quality assessment tool for sustainable agroecosystem development. Ecological Applications, 11, 1573-1585.

Andrews, S. S., Karlen, D. L., \& Mitchell, J. P. (2002). A comparison of soil quality indexing methods for vegetable production systems in northern California. Agriculture, Ecosystems and Environment, 90, 25-45.

Aparicio, V., \& Costa, J. L. (2007). Soil quality indicators under continuous cropping systems in the Argentinean pampas. Soil and Tillage Research, 96, 155-165.

Arshad, M. A., \& Martin, S. (2002). Identifying critical limits for soil quality indicators in agro-ecosystems. Agriculture, Ecosystems \& Environment, 88, 153-160.

Bastida, F., Zsolnay, A., Hernánde, T., \& García, C. (2008). Past, present and future of soil quality indices: a biological perspective. Geoderma, 147, 159-171.

Brejda, J. J., Moorman, T. B., Karlen, D. L., \& Dao, T. H. (2000). Identification of regional soil quality factors and indicators: I. Central and southern high plains. Soil Science Society of America Journal, 64, 2115-2124.

Castro Filho, C., \& Logan, T. J. (1991). Liming effects on the stability and erodibility of some Brazilian Oxisols. Soil Science Society of America Journal, 55, 1407-1413.

Chantigny, M. H. (2003). Dissolved and water-extractable organic matter in soils: a review on the influence of land use and management practices. Geoderma, 113, 357-380.

Chantigny, M. H., Angers, D. A., Prévost, D., Simard, R. R., \& Chalifour, F. P. (1999). Dynamics of soluble organic C and C mineralization in cultivated soils with varying $\mathrm{N}$ fertilization. Soil Biology and Biochemistry, 31, 543-550.

Chichester, F. W. (1969). Nitrogen in soil organo-mineral sedimentation fractions. Soil Science, 107, 356-363.

Curtin, D., \& Smillie, G. W. (1986). Effects of liming on soil chemical characteristics and grass growth in laboratory and long-term field-amended soils. I. Soil chemistry. Plant and Soil, 95, 15-22.

Doran, J. W., \& Parkin, T. B. (1994). Defining and assessing soil quality. In J. W. Doran, D. C. Coleman, D. F. Bezdicek, \& B. A. Stewart (Eds.), Defining soil quality for a sustainable environment (pp. 1-21). Madison: SSSA Special Publication 35.

Erich, M. S., \& Trusty, G. M. (1997). Chemical characterization of dissolved organic matter released by limed and unlimed forest soil horizons. Canadian Journal of Soil Science, 77, 405-413.

Filep, T., \& Rekasi, M. (2011). Factors controlling dissolved organic carbon (DOC), dissolved organic nitrogen (DON) and DOC/DON ratio in arable soils based on a dataset from Hungary. Geoderma, 162, 312-318.

Fließbach, A., Oberholzer, H. R., Gunst, L., \& Mäder, P. (2007). Soil organic matter and biological soil quality indicators after 21 years of organic and conventional farming. Agriculture, Ecosystems \& Environment, 118, 273-284.

Granatstein, D., \& Bezdicek, D. F. (1992). The need for a soil quality index: local and regional perspectives. American Journal of Alternative Agriculture, 7, 12-16.

Gregorich, E. G., Carter, M. R., Angers, D. A., Monreal, C. M., \& Ellert, B. H. (1994). Towards a minimum data set to assess soil organic matter quality in agricultural soils. Canadian Journal of Soil Science, 74, 367-385.

Guggenberger, G., Zech, W., \& Schulten, H. R. (1994). Formation and mobilization pathways of dissolved organic-matter evidence from chemical structural studies of organic-matter fractions in acid forest floor solutions. Organic Geochemistry, 21, 51-66.

Haynes, R. J. (2000). Labile organic matter as an indicator of organic matter quality in arable and pastoral soils in New Zealand. Soil Biology and Biochemistry, 32, 211-219.

Haynes, R. J. (2005). Labile organic matter fractions as central components of the quality of agricultural soils: an overview. Advances in Agronomy, 85, 221-268.

Haynes, R. J., \& Tregurtha, R. (1999). Effects of increasing periods under intensive arable vegetable production on biological, chemical and physical indices of soil quality. Biology and Fertility of Soils, 28, 259-266.

Herrick, J. E., Brown, J. R., Tugel, A., Shaver, P. L., \& Havstad, K. M. (2002). Application of soil quality to monitoring and management: paradigms from rangeland ecology. Agronomy Journal, 94, 3-11.

ISO 16072,2002 . Soil quality — laboratory methods for determination of microbial soil respiration.

Jászberényi, I., Loch, J., \& Sarkadi, J. (1994). Experiences with $0.01 \mathrm{M} \mathrm{CaCl} 2$ as an extraction reagent for use as a soil testing procedure in Hungary. Communications in Soil Science and Plant Analysis, 25, 1771-1777.

Ji, C. J., Yang, Y. H., Han, W. X., He, Y. F., Smith, J., \& Smith, P. (2014). Climatic and edaphic controls on soil $\mathrm{pH}$ in alpine grasslands on the Tibetan Plateau, China: a quantitative analysis. Pedosphere, 24, 39-44.

Jones, D. L., Healey, J. R., Willett, V. B., Farrar, J. F., \& Hodge, A. (2005). Dissolved organic nitrogen uptake by plants - an important $\mathrm{N}$ uptake pathway? Soil Biol. Biochemistry, 37, 413-423.

Jones, D. L., Simfukwe, P., Hill, P. W., Mills, R. T. E., \& Emmett, B. A. (2014). Evaluation of dissolved organic 
carbon as a soil quality indicator in national monitoring schemes. PLoS One, 9, 1-6.

Kalbitz, K., Solinger, S., Park, J. H., Michalzik, B., \& Matzner, E. (2000). Controls on the dynamics of dissolved organic matter in soils: a review. Soil Science, 165, 277-304.

Karlen, D. L., Mausbach, M. J., Doran, J. W., Cline, R. G., Harris, R. F., \& Schuman, G. E. (1997). Soil quality: a concept, definition, and framework for evaluation. Soil Science Society of America Journal, 6, 4-10.

Kemmitt, S. J., Wright, D., Goulding, K. W. T., \& Jones, D. L. (2006). $\mathrm{pH}$ regulation of carbon and nitrogen dynamics in two agricultural soils. Soil Biology and Biochemistry, 38, 898-911.

Liebig, M. A., Varvel, G., \& Doran, J. (2001). A simple performance-based index for assessing multiple agroecosystem functions. Agronomy Journal, 93, 313-318.

Loeppert, R. H., \& Suarez, D. L. (1996). Carbonate and gypsum. In J. M. Bigham (Ed.), Methods of soil analysis. Part 3. Chemical methods (pp. 437-474). Madison: SSSA and ASA.

Marschner, B., \& Kalbitz, K. (2003). Controls of bioavailability and biodegradability of dissolved organic matter in soils. Geoderma, 113, 211-235.

McClain, M. E., Richey, J. E., Brandes, J. A., \& Pimentel, T. P. (1997). Dissolved organic matter and terrestrial-lotic linkages in the central Amazon basin of Brazil. Global Biogeochemical Cycles, 11, 295-311.

Mehlich, A. (1948). Determination of cation- and anion-exchange properties of soils. Soil Science, 66, 429-445.

Michalzik, B., Kalbitz, K., Park, J. H., Solinger, S., \& Matzner, E. (2001). Fluxes and concentrations of dissolved organic carbon and nitrogen: a synthesis for temperate forests. Biogeochemistry, 52, 173-205.

MSZ-08-0206/2 (1978). Evaluation of some chemical properties of the soil. Laboratory tests. ( $\mathrm{pH}$ value, phenolphtaleine alkalinity expressed in soda, all water soluble salts, hydrolite (y1-value) and exchanging acidity (y2-value). Budapest:(In Hungarian) Hungarian Standard Association.

MSZ-08-0215 (1978). Determination of the cation adsorption capacity of the soil. Modified Mechlich technique. Budapest:(In Hungarian) Hungarian Standard Association.

MSZ-08-0452 (1980). Use of high-capacity analyser systems for soils analyses. Quantitative determination of the organic carbon content of the soil on Contiflo analyzer system. Budapest:(In Hungarian) Hungarian Standard Association.

MSZ-08-1721-3 (1986). Soil analysis of agricultural land treated with sewage and sewage sludge. Analysis of soil biological activity by method of dehydrogenase enzyme activity. Budapest:(In Hungarian) Hungarian Standard Association.

MSZ-08-1931 (1984). Cellulose-decomposing test for the characterization of the microbiological condition of the soils treated by organic wastes. Budapest:(In Hungarian) Hungarian Standard Association.

Myers, R. J. K., \& McGarity, J. W. (1971). Factors influencing high denitrifying activity in subsoil of solodized solonetz. Plant and Soil, 35, 145-160.

Neff, J. C., \& Asner, G. P. (2001). Dissolved organic carbon in terrestrial ecosystems: synthesis and a model. Ecosystems, 4, $29-48$.

Nichols, J. D. (1984). Relation of organic carbon to soil properties and climate in the Southern Great Plains. Soil Science Society of America Journal, 48, 1382-1384.
Ódor, L., Wanty, R. B., Horváth, I., \& Fügedy, U. (1998). Mobilization and attenuation of metals downstream from a base-metal mining site in the Matra Mountains, northeastern Hungary. Journal of Geochemical Exploration, 65, 47-60.

Qi, Y., Darilek, J. L., Huang, B., Zhao, Y., Sun, W., \& Gu, Z. (2009). Evaluating soil quality indices in an agricultural region of Jiangsu Province, China. Geoderma, 149, 325-334.

Quiroga, A. R., Buschiazzo, D. E., \& Peinemann, N. (1999). Soil compaction is related to management practices in the semiarid Argentine pampas. Soil and Tillage Research, 52, 21-28.

Rochette, P., \& Gregorich, E. G. (1998). Dynamics of soil microbial biomass $\mathrm{C}$, soluble organic $\mathrm{C}$ and $\mathrm{CO} 2$ evolution after three years of manure application. Canadian Journal of Soil Science, 78, 283-290.

Römkens, P. F. A. M., \& Dolfing, J. (1998). Effect of Ca on the solubility and molecular size distribution of DOC and $\mathrm{Cu}$ binding in soil solution samples. Environmental Science \& Technology, 32, 363-369.

Silveira, M. L. (2005). Dissolved organic carbon and bioavailability of $\mathrm{N}$ and $\mathrm{P}$ as indicators of soil quality. Scientia Agricola, $62,502-508$.

Silverstein, R. M., Bassler, G. C., \& Morrill, T. C. (1974). Spectrometric identification of organic compounds. New York:Wiley.

Sollins, P., Homann, P., \& Caldwell, B. A. (1996). Stabilization and destabilization of soil organic matter: mechanisms and controls. Geoderma, 74, 65-105.

Stockle, C. O., \& Debaeke, P. (1997). Modeling crop nitrogen requirements: a critical analysis. European Journal of Agronomy, 7, 161-169.

Tombácz, E., \& Rice, J. A. (1999). Changes of colloidal state in aqueous systems of humic acids. In E. Ghabbour, \& A. G. Davies (Eds.), Understanding humic substances. Advanced methods, properties and applications (pp. 69-78). Cambridge: The Royal Society of Chemistry.

Undurraga, P. D., Zagal, E. V., Sepúlveda, G. W., \& Valderrama, N. V. (2009). Dissolved organic carbon and nitrogen in andisol for six crop rotations with different soil management intensity. Chilean Journal of Agricultural Research, 69, 445-454.

van Hees, P. A. W., Jones, D. L., Finlay, R., Godbold, D. L., \& Lundström, U. (2005). The carbon we do not see-the impact of low molecular weight compounds on carbon dynamics and respiration in forest soils: a review. Soil Biology and Biochemistry, 37, 1-13.

Vance, G. F., \& David, M. B. (1992). Dissolved organic carbon and sulphate sorption by spodosol mineral horizons. Soil Science, 154, 136-144.

Várallyay, G. (1994). Soil databases for sustainable land use: Hungarian case study. In D. J. Greenland, \& I. Szabolcs (Eds.), Soil resilience and sustainable land use (pp. 469495). Oxon: CAB International.

Wagner, J. G. (1973). Properties of the Michaelis-Menten equation and its integrated form which are useful in pharmacokinetics. Journal of Pharmacokinetics and Biopharmaceutics, 1, 103-121.

Walkley, A., \& Black, I. A. (1934). An examination of the Degtjareff method for determining organic carbon in soils: effect of variations in digestion conditions and of inorganic soil constituents. Soil Science, 63, 251-263. 
Wang, S. H., Shi, X. Z., Zhao, Y. C., Weindorf, D. C., Yu, D. S., Xu, S. X., Tan, M. Z., \& Sun, W. X. (2011). Regional simulation of soil organic carbon dynamics for dry farmland in east China by coupling a 1:500 000 soil database with the century model. Pedosphere, $21,277-287$.

Weishaar, J. L., Aiken, G. R., Bergamaschi, B. A., Fram, M. S., Fujij, R., \& Mopper, K. (2003). Evaluation of specific ultraviolet absorbance as an indicator of the chemical composition and reactivity of dissolved organic carbon. Environmental Science and Technology, 37, 4702-4708.
You, S. J., Yin, Y., \& Allen, H. E. (1999). Partitioning of organic matter in soils: effects of $\mathrm{pH}$ and water/soil ratio. Science of the Total Environment, 227, 155-160.

Zech, W., Senesi, N., Guggenberger, G., Kaiser, K., Lehmann, J., Miano, T. M., Miltner, A., \& Schroth, G. (1997). Factors controlling humification and mineralization of soil organic matter in the tropics. Geoderma, 79, 117-161.

Zmora-Nahum, S., Hadar, Y., \& Chen, Y. (2007). Physicochemical properties of commercial composts varying in their source materials and country of origin. Soil Biology and Biochemistry, 39, 1263-1276. 